\begin{tabular}{|c|c|c|c|c|c|c|}
\hline \multirow{4}{*}{ Impact Factor: } & ISRA (India) & $=3.117$ & SIS (USA) & $=0.912$ & ICV (Poland) & $=6.630$ \\
\hline & ISI (Dubai, UAE & $=0.829$ & РИНЦ (Russia & $=0.156$ & PIF (India) & $=1.940$ \\
\hline & GIF (Australia) & $=0.564$ & ESJI (KZ) & $=8.716$ & IBI (India) & $=4.260$ \\
\hline & JIF & $=1.500$ & SJIF (Morocco & $=5.667$ & OAJI (USA) & $=0.350$ \\
\hline
\end{tabular}

\begin{tabular}{|c|c|}
\hline $\begin{array}{l}\text { SOI: } \frac{1.1 / \mathrm{TA}}{} \\
\text { International Sc } \\
\text { Theoretical \& A }\end{array}$ & $\begin{array}{l}S \text { DOI: } 10.15863 / T A S \\
\text { ientific Journal } \\
\text { pplied Science }\end{array}$ \\
\hline p-ISSN: 2308-4944 (print) & e-ISSN: 2409-0085 (online) \\
\hline Year: 2019 & Volume: 72 \\
\hline Published: 08.04.2019 & http://T-Science.org \\
\hline
\end{tabular}

SECTION 7. Mechanics and machine construction.
QR - Issue

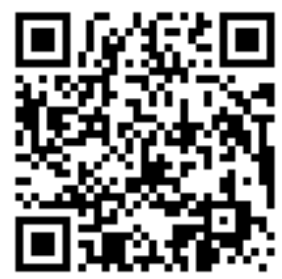

M.Sc.Eng., Corresponding Member of International Academy of Theoretical and Applied Sciences, Lecturer of Vladimir Industrial College, Russian Federation https://orcid.org/0000-0002-2747-552X chemezov-da@yandex.ru

Svetlana Tyurina Lecturer of Vladimir Industrial College, Russian Federation

Tatyana Komarova Lecturer of Vladimir Industrial College, Russian Federation

Alexey Averyanov Student of Vladimir Industrial College, Russian Federation

Lyubov Suvorova Student of Vladimir Industrial College, Russian Federation

Oleg Stepanov Student of Vladimir Industrial College, Russian Federation

Elena Lezova Master of Industrial Training, Vladimir Industrial College, Russian Federation

\title{
STRESSES IN A STEEL RING AT CLAMPING IN A THREE-JAW CHUCK
}

Abstract: The results of experimental researches of stress-strain state of a metallic ring with a wall thickness from 0.5 to $10 \mathrm{~mm}$ at a classical clamping scheme in a three-jaw self-centering lathe chuck are presented in the article. The dependence analysis of shear stress of the ring from the wall thickness and arising bending moment $\tau(S ; M)$ was performed.

Key words: a ring, thickness, stress, moment, load.

Language: English

Citation: Chemezov, D., et al. (2019). Stresses in a steel ring at clamping in a three-jaw chuck. ISJ Theoretical \& Applied Science, 04 (72), 11-14.

Soi: http://s-o-i.org/1.1/TAS-04-72-2 Doi: crossef https://dx.doi.org/10.15863/TAS.2019.04.72.2

\section{Introduction}

Boring of thin-walled metallic rings is performed on universal or automated lathes at observance of the certain conditions of mechanical processing. Excessive clamping of a processed workpiece by jaws of a lathe chuck leads to a distortion of a geometric shape of the ring [1 -9]. This distortion is expressed in a deflection of an outer diameter, and after boring and the inner diameter of the ring in places of clamping [6]. In turn, insufficient clamping force can 


\begin{tabular}{|c|c|c|c|c|c|c|}
\hline \multirow{4}{*}{ Impact Factor: } & ISRA (India) & $=3.117$ & SIS (USA) & $=0.912$ & ICV (Poland) & $=6.630$ \\
\hline & ISI (Dubai, UAE & $=0.829$ & РИНЦ (Russia & $=\mathbf{0 . 1 5 6}$ & PIF (India) & $=1.940$ \\
\hline & GIF (Australia) & $=0.564$ & ESJI (KZ) & $=8.716$ & IBI (India) & $=4.260$ \\
\hline & JIF & $=1.500$ & SJIF (Morocco & $=5.667$ & OAJI (USA) & $=0.350$ \\
\hline
\end{tabular}

lead to snatching of the ring from the jaws of the lathe chuck under the action of cutting forces. Special machine retaining devices excluding elastic and plastic deformations of the workpieces are used at turning of a large number of the thin-walled rings. The presented clamping scheme is used at mechanical processing of the small number of the rings in an experimental (individual) production. Prediction of stress-strain state of the metallic ring at clamping in the three-jaw lathe chuck can be obtained by thickness changing of the processed workpiece and mathematical processing of the results of performed experiments.

\section{Materials and methods}

Stress-strain state of the metallic ring was determined in accordance with the loading scheme (the Fig. 1). The ring is clamped with some force in the lathe chuck at the outer cylindrical diameter by three self-centering jaws. There were performed 39 experiments in which thickness $(S)$ of the ring from 0.5 to $10 \mathrm{~mm}$ was changed. A changing step of the ring thickness was adopted $0.25 \mathrm{~mm}$.

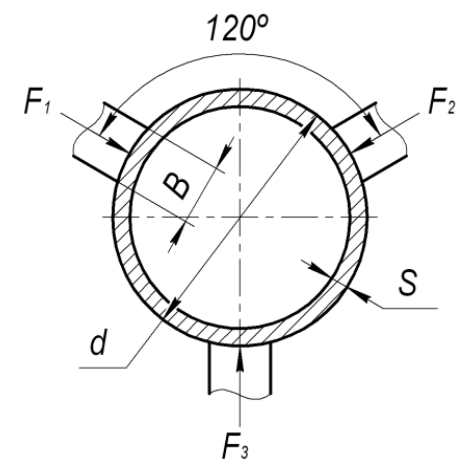

Figure 1 - The loading scheme of the metallic ring clamped by three jaws of the lathe chuck.

The other source parameters were taken constant for each performed experiment: the outer diameter of the ring $d$ is $50 \mathrm{~mm}$; external force on the ring $F_{1}, F_{2}$, $F_{3}$ is $1000 \mathrm{~N}$; the width of the jaw of the lathe chuck $B$ is $12 \mathrm{~mm}$; yield stress of the metallic ring $R_{e}$ is 355 $\mathrm{N} / \mathrm{mm}^{2}$; the allowable stress factor of the ring material is 0.6 .

\section{Results and discussion}

The diagrams of stress-strain state of the ring material (the axial, moment and UC diagrams) when $S=3 \mathrm{~mm}$ are presented in the Fig. 2. On the diagrams it is seen that axial stresses in the ring material and bending moment have negative values. However, in material of the deformed ring there are arised stresses with the positive values. Thus, you can say that the clamped metallic ring is exposed simultaneously by tension and compression.

Herewith, maximum stresses occur in material volumes of the thin-walled ring which do not expose by external load. The coefficient of deformation of the metallic ring is: 73 when $S=0.5 \mathrm{~mm} ; 2.8$ when $S=$ $2.5 \mathrm{~mm}$; 0.7 when $S=5 \mathrm{~mm}$; 0.3 when $S=7.5 \mathrm{~mm}$ and 0.1 when $S=10 \mathrm{~mm}$.

The dependence of inertia moment $(J)$ from the ring thickness is presented in the Fig. 3. Inertia moment of the ring is increased with increasing of thickness (at changing only the inner diameter). Increasing of inertia moment in 1000 times is occurred at tenfold increasing of the ring thickness (from the minimum to maximum value).

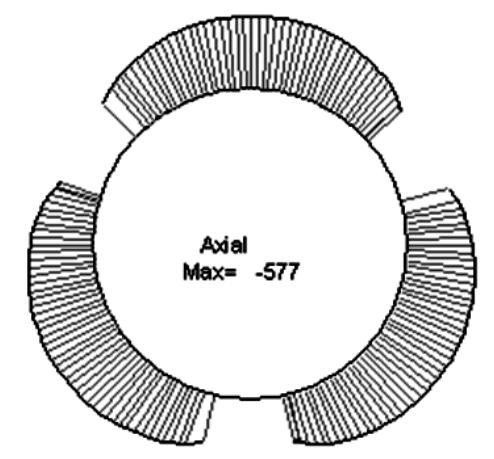

A)

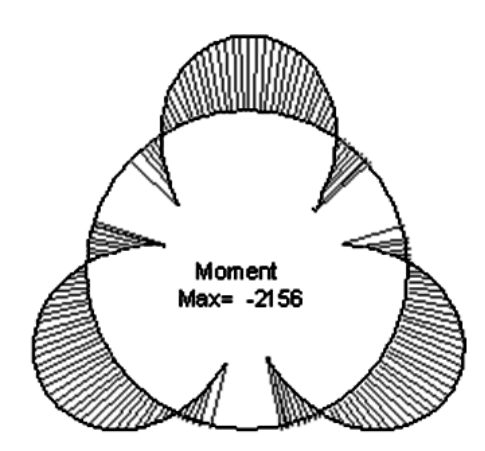

B)

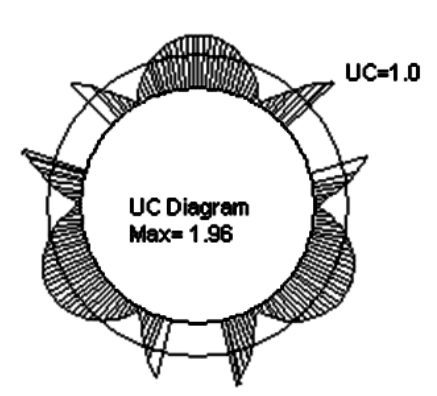

C)

Figure 2 - The diagrams of stress-strain state of the metallic ring when $S=3 \mathbf{m m}(A-$ the axial diagram, $B-$ the moment diagram, $C$ - the UC diagram). 


\begin{tabular}{|c|c|c|c|c|c|c|}
\hline \multirow{4}{*}{ Impact Factor: } & ISRA (India) & $=3.117$ & SIS (USA) & $=0.912$ & ICV (Poland) & $=6.630$ \\
\hline & ISI (Dubai, UAE & $=0.829$ & РИНЦ (Russia & $=\mathbf{0 . 1 5 6}$ & PIF (India) & $=1.940$ \\
\hline & GIF (Australia) & $=0.564$ & ESJI (KZ) & $=8.716$ & IBI (India) & $=4.260$ \\
\hline & JIF & $=1.500$ & SJIF (Morocco & $=5.667$ & OAJI (USA) & $=0.350$ \\
\hline
\end{tabular}

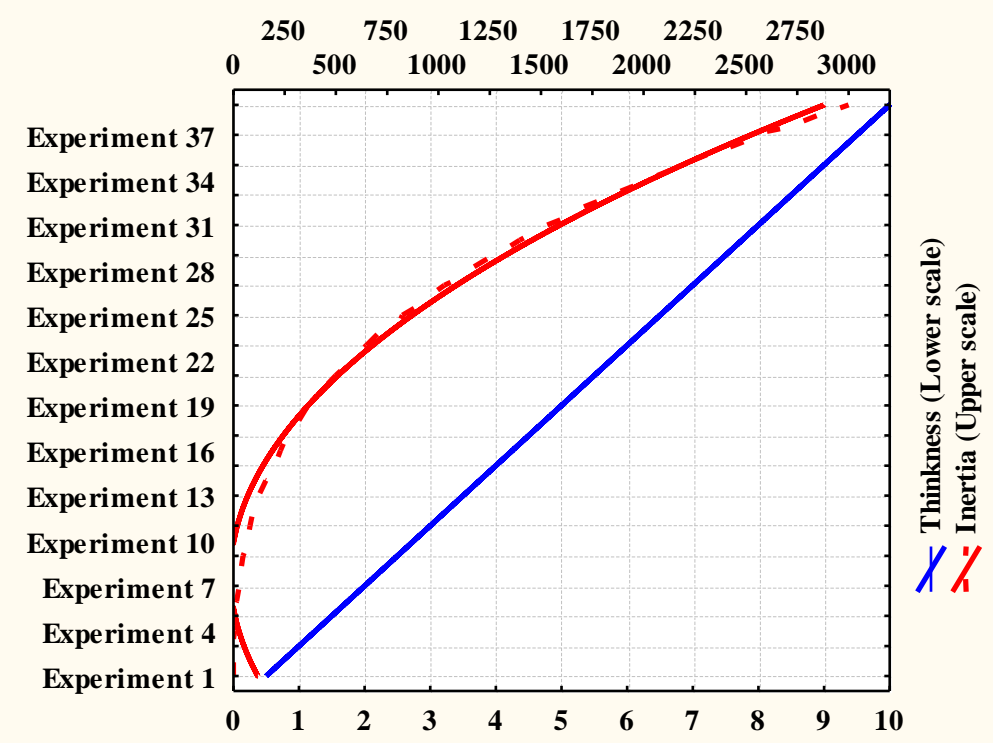

Figure 3 - The dependence of inertia moment from the ring thickness.

If the ring thickness does not change, then at constant external force, bending moment $(M)$ will not change. By changing the ring thickness in the adopted range, the value of bending moment changes, and therefore, and shear stress $(\tau)$ of the ring material. How it is changing shear stress will show integration of the function $\tau(S ; M)=-28.2651-0.1619 M+$ $26.068 S-2.7608 \times 10^{-5} M^{2}+0.0096 M S-0.3613 S^{2}$. Let us choose the integration range by the ring thickness based on the analysis of the dependence graph $J(S)$.

$$
\int_{3}^{10} d S \int_{-2156}^{-1508} d M\left[\begin{array}{c}
26.068 S-2.7608 \times 10^{-5} M^{2}+ \\
0.0096 M S-0.3613 S^{2}-28.2651- \\
-0.1619 M
\end{array}\right],
$$

where $-2156 \mathrm{~N} \times \mathrm{m}$ and $-1508 \mathrm{~N} \times \mathrm{m}$ are the lower and upper limits of integration for bending moment, respectively.

Let us integrate by the ring thickness

$$
\int_{3}^{10}\left[\begin{array}{c}
26.068 S-2.7608 \times 10^{-5} M^{2}+0.0096 M S- \\
-0.3613 S^{2}-28.2651-0.1619 M
\end{array}\right] d S
$$

1. $\left.\frac{26.068 S^{2}}{2}\right|_{3} ^{10}=1303.4-117.306=1186.094$

$$
2 .
$$$$
2.7608 \times 10^{-5} M^{2} S_{3}^{10}=27.608 \times 10^{-5} M^{2}-
$$$$
-8.2824 \times 10^{-5} M^{2}=19.3256 \times 10^{-5} M^{2}
$$

3. $\left.\frac{0.0096 M S^{2}}{2}\right|_{3} ^{10}=0.48 M-0.0432 M=0.4368 M$

4. $\left.\frac{0.3613 S^{3}}{3}\right|_{3} ^{10}=120.4333-3.2517=117.1816$

5. $\left.28.2651 S\right|_{3} ^{10}=282.651-84.7953=197.8557$

6. $\left.0.1619 M S\right|_{3} ^{10}=1.619 M-0.4857 M=1.1333 M$

$$
\begin{gathered}
1186.094-19.3256 \times 10^{-5} M^{2}+0.4368 M- \\
\text { 7. } \quad-117.1816-197.8557-1.1333 M= \\
=871.0567-19.3256 \times 10^{-5} M^{2}-0.6965 M
\end{gathered}
$$
moment

Let us convert $\mathrm{mm}$ to $\mathrm{m}$ and integrate by bending

$$
\begin{aligned}
& \int_{-2156}^{-1508}\left[0.871-19.3256 \times 10^{-8} M^{2}-0.0007 M\right] d M \\
& \text { 1. } \begin{array}{c}
\left.0.871 M\right|_{-2156} ^{-1508}=-1313.468-(-1877.876)= \\
=564.408
\end{array} \\
& \text { 2. }\left.\frac{19.3256 \times 10^{-8} M^{3}}{3}\right|_{-2156} ^{-1508}=-220.91- \\
& \text { 3. }\left.\frac{0.0007 M^{2}}{2}\right|_{-2156} ^{-1508}=795.92-1626.9176= \\
& =-830.9976 \\
& \text { 4. } \begin{array}{c}
564.408-424.682-(-830.9976)= \\
=970.7236 N / m^{2}
\end{array}
\end{aligned}
$$

The calculation result shows that tension deformations of the ring material are prevailed over compression deformations. Therefore, inevitably there is occurred a deviation from circularity of the ring after machining.

\section{Conclusion}

Based on the performed experiments and the mathematical calculations by determination of stressstrain state of the metallic ring at load can be drawn the following conclusions:

1. If the ring thickness more than $3 \mathrm{~mm}$ that inertia moment does not change significantly, what says about large stresses in material.

2. Optimal forces (boundaries of integration) were selected by means of the mathematical 


\begin{tabular}{|c|c|c|c|c|c|c|}
\hline \multirow{4}{*}{ Impact Factor: } & ISRA (India) & $=3.117$ & SIS (USA) & $=0.912$ & ICV (Poland) & $=6.630$ \\
\hline & ISI (Dubai, UAE & $=0.829$ & РИНЦ (Russia) & $=0.156$ & PIF (India) & $=1.940$ \\
\hline & GIF (Australia) & $=0.564$ & ESJI (KZ) & $=8.716$ & IBI (India) & $=4.260$ \\
\hline & JIF & $=1.500$ & SJIF (Morocco & $=5.667$ & OAJI (USA) & $=0.350$ \\
\hline
\end{tabular}

calculations in which minimum elastic and plastic deformations of the ring were defined.

\section{References:}

1. Litvin, A. V. (2014). Technological systems lathe and its effects on processing nonrigid parts. Bulletin of Sevastopol national technical University, 151, 81-86.

2. Frolov, A. A., \& Vasilyev, A. S. (2016). The research of strain state of billets of the type rings when installed on the machines of the turning group. All-Russian scientific and technical conference of students «Student research spring of 2016: Mechanical Engineering Technology», (pp.1-21).

3. Kopetsky, A. A., Nosenko, V. A., \& Tyshkevich, V. N. (2013). Research of elastic deformations of bearings rings at fixing in jaw chuck. Izvestija TulGU, №5, 159-166.

4. Morgunov, A. P., \& Chkhetiani, E. Yu. (2012). The technological base of machining precision of the thin-walled plane engine details. The Journal Omsk Scientific Bulletin, №1 (107), 130132.

5. Morgunov, A. P., \& Chkhetiani, E. Yu. (2012). The influence of technological system rigid factor to the machining precision of thin-walled variable-section flange. The Journal Omsk Scientific Bulletin, №2 (110), 70-72.

6. Eremeykin, P. A., \& Zhargalova, A. D. (2017). Automation of assignment of rational thinwalled parts turning mode. Engineering Journal: Science \& Innovation, 2, 1-15.

7. Gavryushin, S. S., Zhargalova, A. D., Lazarenko, G. P., \& Semisalov, V. I. (2015). The Method of Determining the Conditions for Machining Thin-Walled Parts. Proceedings of Higher Educational Institutions. Machine Building, № 11, 53-60.

8. Lastovskii, P. N. (2010). Ensuring the accuracy of specified requirements with regard to Automatic turning thin-walled parts. Cand. tehn. sci. diss., OmGTU publ., (p.226).

9. Chumakov, I. V. (2015). Turning non-solid flanges on the CNC machine tool. Technique and technology of modern productions, 150-154.

10. GOST 2.308-2011. Unified system of design documentation. Representation of limits of forms and surface lay-out on drawings. 